Hu, H., Oslick, M., \& Wake, D. (2017). Innovative Web 2.0 Technologies to Support Struggling Readers. Journal of Educational Technology Development and Exchange, 10(1), 55-71.

\title{
Innovative Web 2.0 Technologies to Support Struggling Readers
}

\author{
Haihong (Helen) Hu \\ University of Central Arkansas \\ Mary Ellen Oslick \\ Stetson University \\ Donna Wake \\ University of Central Arkansas
}

\begin{abstract}
Most Web 2.0 technologies are either free or inexpensive, making them accessible for teachers to use for instructional purposes, especially to assist diverse students from lower socioeconomic backgrounds. This article discusses the qualitative findings of a mixed-methods study that investigated how a group of candidates in a reading licensure graduate program responded to Web 2.0 technology integration when working with struggling readers, including their perceptual reaction and their implemented practice. The results from the study may help K-12 classroom teachers and teacher educators better understand how to include technologies in working with teacher candidates and assist them in designing instructional practices to support all learners.
\end{abstract}

Keywords: Reading, teacher education, technology integration

\section{Introduction}

The term "Web 2.0" refers to webbased technologies where users can create, edit and discuss content through a social and collaborative use of the Internet (Anderson, 2007; O’Reilly, 2005). Examples of tools in this category include: Wordle, ToonDoo, Voicethread, Voki, and Storybird. Most of these technologies are either free or inexpensive, which makes them accessible to all students (Ertmer, Ottenbreit-Leftwich, Sadic, Sendurur, \& Sendurur, 2012). Teachers can take advantage ofthese technologies for instructional purposes, especially to assist diverse students with lower socioeconomic status (Hobgood \& Ormsby, 2011; U.S. Department of Education, 2017).

Many professional organizations with guiding standards for teacher education (e.g., International Society for Technology in Education (2014)) include requirements for developing teachers' technology proficiencies. Additionally, trends in technology development impacting content area knowledge and skills (e.g., literacy, math, science) make technology integration central to learning in these subject areas (e.g., International Literacy Association, 2010) 
(U.S. Department of Education, 2017).

Technology supported instructiona practices can support learning for diverse students, students from low socioeconomic backgrounds, and at-risk students((DarlingHammond, Zielezinski, \& Goldman, 2014 Molnar, 2014; U.S. Department of Education, 2017). According to a recent meta-analysis, key variables for technology integration that can assist interactive learning experiences and using technology to explore and create (rather han to "drill and kill")(Darling-Hammond, Zielezinski, \& Goldman, 2014). Interactive learning refers to computer-based application such as simulations, games, word processing, and technology applications. Technology hat allows students to create conten themselves rather than being passive receivers (e.g., multimedia content creation such as digital storytelling and creating graphic representations of content) has been found he effect on student learning, student engagement, student self-efficacy, attitudes toward school, and content and skil mastery (Darling-Hammond, Zielezinski, \& Goldman, 2014;U.S. Department of Education, 2017).

As a result of these trends and the potentia of technology integration to support at-risk learners, it is essential for teacher education learners, it is essential for teacher education candidates to develop their knowledge and
skills regarding emerging technologies. skills regarding emerging technologies. powerful learning relies on teacher ability to design and implement experiences that are guided and include student social interaction (e.g., collaboration, peer review) (Darling Hammond, et al., 2014). At-risk students can benefit from technology supported learning, as long as their experiences include high interactivity and engagement with the content in multiple formats (Darling-Hammond, Zielezinski, \& Goldman, 2014). This study

builds on these recommendations in guiding candidates in a reading licensure program to enact these best practices.

\section{Literature Review}

\subsection{Best Practices for Reading Instruction}

"Effective reading instruction helps learners make sense of written language" (National Council of Teachers of English, 2004). The definition of literacy has changed due to the influence of Web 2.0 technologies (Borsheim, Merritt, \& Reed, 2008) and new conceptions of literacy viewed as social and global (Cope \& Kalantzis, 2000; Larson, 2008; McPherson, Wang, Hsu, \& Tsuei, 2007). Literacy is no longer defined as print on a page. Current conceptions of literacy are social and multimod words, and sounds. Common reading methods long considered best practices, like guided reading, have evolved through the integration of technology in literacy instruction to include multimodal practices(Iaquinta, 2006; Jewitt, 2008).

Guided reading is a research-based approach to prevent reading difficulties. It is particularly suitable for addressing the challenges of reading instruction regardless of age of student (International Reading Association/The National Association for the Education of Young Children, 1998; National Council of Teachers of English, 2002). The focus of guided reading is to cultivate a "self-extending system" that allows the reader to learn about the process of reading (Iaquinta, 2006).Students develop an understanding about reading through selfmonitoring and graphophonemic cues, cross-checking to confirm their reading, self-correcting, and defining new words using multiple sources of information. During this process, learners improve the accuracy, speed, and fluency of their reading. Eventually the application of these strategies become automatic. In current climates, this work is increasingly multimodal.

Recent research has emphasized reading as a process that includes multiliteracies --- a concept of literacy that focuses on the multimodal and digital nature of literacy practices. The multiliteracies model emphasizes changes in what it means to be literate (Jewitt, 2008). Multiliteracies draws from the growing complexity of text usingnonlinguistic, "multimodal forms of representation and communication, particularly, but not limited to, those affiliated with new technologies" (p. 245). "From multimodal perspective, image, action, and so forth are referred to as modes, as organized sets of semiotic resources for meaning making" (Jewitt, 2008, p. 246).

Despite increasing multimodal contexts, Mills (2010) suggested that not all of today's youngsters are "digital natives" based on her study of adolescent's multimodal literacy practices. She contended that to engage students in multimodal textual practices, it is not sufficient to only adapt the curriculum to their interests and include the latest "catchy" technology tool. Rather, teachers should improve students' knowledge and skills of both literacy and technology by providing expert scaffolding explicit in their instructiona practice (Borsheim, Merritt, \& Reed, 2008 Mills 2010). For teachers to do this, they need to feel comfortable with and be knowledge of technologies that will support their students'literacy work (Wake, 2013).

\subsection{Technology Tools for Teaching and} Learning

Online technology is constantly evolving, and the advancement of technologies has brought about an expansion in the types of literacy and in how literacy work in K-12 classrooms is enacted. Cyberlearning literacy refers to "the knowledge and skills needed for successful use of Web 2.0 tools" (Smaldino, Lowther, \& Russell, 2012, p.126). The face of literacy has changed over the last decade due to the advent of Web 2.0 technologies, and many digital-age communication and teaching and learning with students across the K-12 grade span. Popular technologies teachers can use to support students' literacy work include Wordle, ToonDoo, Voicethread, Voki, and Storybird (Wake, 2013).

Wordle (http://www.wordle.net/) is a Web 2.0 multimedia tool that creates Word Clouds using key word frequency counts. The more frequently a word is used, the larger it will appear in the overall Word Cloud picture. It allows users to customize the appearance, fonts, and colors of a Word Cloud picture Taylor (2012) found in working with six 3rd grade reluctant writers that use of Wordle resulted in higher motivation to write as well as longer and more frequent responses to reading. In another case study, Wordle was found to lead to increased student engagement when compared with the traditional Fraye method in two high school graduates' Franger 2014)

Toondoo (http://www.toondoo.com ) is web-based graphic tool that generates comic strips. It allows a user to select how many frames to use for a comic strip, and provides images for the characters, backgrounds, and thought bubbles. It allows you to save publish, print your cartoon or share it with others via social media (e.g., Facebook). In a study abroad course that integrated writing and technology, ToonDoo was found to be helpful for demonstrating cultural appreciation as it could effectively depict conversations with international peers (Oliver, Pritchard, 
\&Watson, 2013). Use of a similar computerbased cartoon tool was found to increase engagement of elementary and middle school students in story writing and resulted in increased character development as seen in character action, pose, and interaction (Madden, Chung, \& Dawson, 2008)

Voice Thread (http://voicethread.com/) is an internet tool which allows users to upload images or videos and to comment on the postings using audio, text, web camera or telephone recordings. In a case study of three students with learning disabilities, Voice thread was found to enhance the learning skills and motivation of students "as they work with multimedia their ideas, and share information --- and all at their own pace and learning level" (Brunvand \& Byrd, 2011, p. 28). Researchers in another study found that multimedia web-authoring tools, such as Voicethread, were able to help 2nd graders overcome the physical difficulty with writing and the need to focus on letter and word formation resulting in their ability to produce richer stories with better quality (O’Byrne, Bailey \& Murrell, 2011).

Voki (http://voki.com ) is a free online service that allows people to create a customized speaking avatar.In one study employing constructivist-based teaching activities, students and teachers collaborated to produce media and learning artifacts and to transfer drama skills to other classroom contexts. In this study, the researcher, who served as a voice coach, designed an avatar in voki.com to introduce herself to the students. Her students also created avatars to create authentic voice files that explained their video game design ideas. This drama e-learning project resulted in improved voice techniques and increased engagement for the student (Baskerville, 2012).

Storybird (http://storybird.com ) is a free

online storytelling tool that provides users with visual images as well as backgrounds. In a study that examined the effect of digital storytelling on EFL young learners' reading and writing performance, Storybird was found to enhance vocabulary learning, reading comprehension and writing skill development of 27 EFL sixth graders in Taiwan (Chuang, Kuo, Chiang, Sud, \& Chang, 2013).

These Web 2.0 technologies allow students to learn things through multiple sensory channels, create images, design visual narratives, build avatars and stories, communicate and collaborate, and explore. The technologies selected for this study encouraged student interest, engagement, the particuly effective for hasson, effective for hands-on, multimedia presentation or creation integrating text, audio, graphic, video modes and teamwork experience (e.g., Voki, Voicethread, ToonDoo) and allow students to read, write, draw, record their own voice, see cause and effect, and to make connections between elements like vocabulary, concept and/or plot (e.g., Storybird, Wordle)

The continual development of technology requires educators to constantly transform and update their skill set in designing, delivering and evaluating $\mathrm{K}-12$ reading instruction. The tools included in this study are only some of those available to teachers to use in instructional planning and implementation. However, these tools are popular and have resonance with teachers and teacher educators (Wake, 2013), and tools meet the recommendations for best-practices in the field (Darling-Hammond, et al., 2014). Additionally, these tools have a low learning curve which may bolster teachers unsure of their own technology skills and provide them with a chance to acquire the confidence and efficacy necessary to explore additional tools for use in their instructional practice to support student engagement (Wake \&Whittingham, 2013).

\section{Rationale for the Project}

In 2010, the National Center for Education Statistics reported that even though almost all classrooms in the United States have at leas one computer with internet access, only $40 \%$ of teachers surveyed regularly used computer for instruction (Gray,Thomas, \& Lewis, 2010). This disparity is concerning given the potential impact of technology integratio in instructional specifically in teaching literacy. In particular, this data is problematic given that the inclusion of technology in literacy instruction could have a positive impact for struggling students and for diverse student populations including low SES students (Darling-Hammond, et al., 2014).

In the state where this study is situated, there is a large discrepancy between the reading achievement of the general populatio at large and the reading achievement of diverse students from lower socioeconomic status. A report from the Annie E. Casey Foundation (2014) revealeda marked reading achievement gap in Arkansasat the fourth grade level: African-American (14.7\%) an Latino $(23.9 \%)$ students had the lowest level of reading proficiency compared to white (38\%) students' proficiency rates. Potentially, technology-infused literacy instruction could have a positive impact on the reading achievement scores of all students in Arkansas including those from diverse backgrounds. Providing teacher candidates with appropriate training is a first step in supporting teachers in the work of technology integration in literacy.

The International Literacy Association Standards (2010) require that candidates for the reading profession should "have deep understanding and knowledge of the elements of a balanced, integrated, and comprehensive literacy curriculum and have developed expertise in enacting that curriculum...using traditional print, digital, and online resources"(Standard 2: Curriculum and Instruction section, para2). Readin professionals should incorporate multiple genres, multiple perspectives, and employ media and communication technologies to prepare learners for the 21 st century literacy tasks (International Literacy Association, 2010). In other words, the ILA standards require reading teachers to integrate technology in their instruction.

Similarly, the recently revised Nationa Educational Technology Standards for Teachers (NETS-T) (International Society for Technology in Education [ISTE], 2014), recommend digital age learning experience and assessments that facilitate studen engagement using digital technologies, collaborative knowledge construction, an creativity for digital age work and learning. These standards were adopted in the design of this study because the graduate student involved are currently serving or are preparing to serve as K-12 teachers and/or reading specialists in the near future.

The benefits of using Web 2.0 for teaching include "(1) interaction, communication and collaboration, (2)knowledge creation, (3) ease of use and flexibility, and (4) writing and technology skills"(An, Aworuwa, Ballard \& Williams, 2009, p.1) and collaborative learning and information sharing (Chu Hwang,Tsai, \& Chen, 2009). Web 2.0 tools were selected for the training in this study because they were readily available and could be applied in classroom use easily to support students' literacy development.

\section{Methods}




\subsection{Purposes of the Study}

This study was conducted within a graduate course titled Diagnosis and Intervention of Reading Difficulties. The course is designed for teacher candidates to explore a variety of remedial methods of teaching reading. Graduate candidates work in the clinical setting (the "Reading Success Center")as clinicians and as literacy coaches by evaluating elementary students from are schools and by providing tutorial assistance. During the course, candidates plan intervention sessions for individual and/or small group of students using the guided reading model. These sessions focus on teaching reading as the process of constructing meaning as well as understanding the interrelation of language and literacy acquisition.

The Web 2.0 Technology Training designed for this study followed the ASSUR model (Smaldino, Lowther, \& Russell, 2012) for technology integration and the "Learning by Doing" (Dewey, 1897) theories. An exploratory study was conducted alongside the training to measure the impact of the professional development (PD) provided. The purpose of this study was to examin whether a technology training on Web 2.0 tools would positively influence reading teacher candidates': 1) acceptance of using Web 2.0 tools, and 2) integration of the Web 2.0 including which tools they would choose and how they would integrate these tools into lesson planning. This article focuses o qualitative responses of the participants an their integration of web 2.0 lesson planning and implementation. The K-12 students' responses are also provided here to examine depth of technology integration impact.

\subsection{Participants}

This research project took place in

two semesters (fall 2012 and fall 2013). Participants were fourteen pre-service or inservice teach who completed all the training procedures constituted the participants in this study. The majority of the participants in this studywere female (only one male participant), and their teaching preferences ranged from early childhood to high school. Some (five) were part of the university's Masters in the Art of Teaching (M.A.T.) program and held undergraduate degrees in fields other than education. These women were completing the M.A.T. degree in anticipation of becoming novice teachers. Of this sub-population, two werice ers, one was a special education aide, and the other two women were unemployed. The remaining nine participants were completing a traditional master's in reading and already held jobs as certified teachers in elementary, middle and high schools. They were enrolled in this course as part of their program seeking a reading specialist endorsement. Three women were African-American and the others were of European descent. The average age of the participants was 26.38 for fall 2012 and average teaching exper verage teaching experience of 2.67 years for fall 2012 and 5.5 years for fall 2013 .

\subsection{Context}

The Reading Success Center serves as the clinical setting for this course and provides elementary-aged students in the Central Arkansas area with support in reading (remediation, enrichment) with the goal of improving student achievement and abilities in literacy learning and increasing students' literacy engagement and motivation. An individual reading success plan An individual reading success plan is formulated for each student based on an intake assessment, and instruction is provided by the graduate candidates enrolled in the reading program coursework. The students served at the Reading Success Center represent diverse backgrounds and needs with many of them coming from lower socioeconomic backgrounds. The student population includes English languages learners, struggling readers, and those with identified learning differences such as dyslexia. In the fall of 2012, the Reading Success Center enrolled 23 students; in the fall of 2013, it enrolled 26 students (See Table 1).

\subsection{Procedure}

The Web 2.0 Technology Training and Integration project lasted for one semester and was repeated with a different cohor in a second semester. The project was implemented through the following eight steps each semester: 1) Pre-Test using the Acceptance of Web 2.0 Technologies 2.0 Technologies in Reading presentation, 3) Web 2.0 Technologies Demonstration, 4) Web 2.0 Tools Practice with the assistance from Job Aids, 5) Web 2.0 Technologies Lesson Planning, 6) Implementing Lessons with struggling readers and researcher observation, 7)Candidate reflection on the lesson and Assessment, 2) Introduction to Using Web

technology integration, and 8) Post-Test using the Acceptance of Web 2.0 Technologies Assessment.

The training lasted about 6 hours (3 hours on two separate evenings) around the mid-point of the semester and covered the first five steps in the overall process. The technologies introduced in the training included Wordle, ToonDoo, Voice Voicethread (Fall 2012) and Wordle, Vok and Storybird (Fall 2013).Except Wordle different Web 2.0 technology tools were selected for the training in the two semesters based on participant and faculty preferences. Candidates were given an option for technologies they preferred to work with based on an overview presentation and faculty pre-selection of options. Candidates were provided choice to empower them and increase their engagement in this work.

\subsection{Data Sources and Analysis}

Both quantitative and qualitative methodologies were employed to investigate participants' acceptance and integration of the Web 2.0 Technologies. Data were

Table 1. Demographic Information of Reading Success Center K-12 Students

\begin{tabular}{|c|c|c|c|c|}
\hline \multirow{2}{*}{$\begin{array}{c}\text { Demographic } \\
\text { Information }\end{array}$} & \multicolumn{2}{|c|}{ Number } & \multicolumn{2}{c|}{ Percentage } \\
\hline & Fall 2012 & Fall 2013 & Fall 2012 & Fall 2013 \\
\hline Male & 13 & 17 & $56 \%$ & $65 \%$ \\
\hline Female & 10 & 9 & $44 \%$ & $35 \%$ \\
\hline Low SES & 9 & 15 & $39 \%$ & $58 \%$ \\
\hline Minority & 11 & 17 & $48 \%$ & $65 \%$ \\
\hline Englis Language & 1 & 5 & $4 \%$ & $19 \%$ \\
\hline Learner & & & & \\
\hline
\end{tabular}

Volume 10, No. 1, April, 2017 
notes, analyses of lesson plans, and analyses of lesson reflections. The questionnaire used to gauge teacher candidates' pre-, and postresponses to technology integration was titled "Acceptance on Using the Web 2.0 Technologies" - a tool adapted from Yoo, \& Huang's (2011) study. Participants' responses to the questionnaire were analyzed using descriptive statistics. For the purposes of this article, the qualitative observation notes and lesson plan documents and reflections will be emphasized. Quantitative data will be provided merely to provide context for the qualitative data.

The researchers coded the participants' reflections and lesson plans as emergent data with the intent of developing themes (Straus \& Corbin, 1998). To analyze these data, the researchers read participants' lesson plans and reflections and highlighted commen units or references (i.e., word(s). phrase(s) or sentence(s) that described a technology integration strategy or perception (opencoding) to capture main ideas, themes. Then, a search was performed for patterns across all participants (axial coding) to portray relationships. Finally, technology integration strategies and perceptions were summarized with the patterns found across all participants into three categories (i.e., Positive Perception of Experience, Uses of Technology for Literacy Instruction, and Issues and Challenges).

\section{Results}

Acceptance of Web 2.0.Based on the responses to the questionnaire, there were positive changes in Perceived Usefulness in learning from the pre- to the post-test. In fall 2012, the number of people who though Wordle was useful for learning stayed the same at $5(62.5 \%)$. The number of people who thought ToonDoo and Voicethread were useful lowered from $5(62.5 \%)$ and $3(37.5 \%)$ to $3(37.5 \%)$ and $1(12.5 \%)$ respectively. In fall 2013, the number of people who thought Wordle was useful stayed the same at 2 $(33.3 \%)$. The number of people who thought Voki and Storybird were useful rose from 0 $(0.0 \%)$ for both to $4(66.7 \%)$ respectively.

At the end of the study there were much more encouraging perceptions regarding ease of using the technologies experienced in the study. In fall 2012, the number of people who thought, "Learning to use Wordle, ToonDoo or Voice thread was easy," rose from $0(0 \%)$ for all three to $4(50 \%), 3(37.5 \%)$ and $3(37.5 \%)$ respectively. In fall 2013 , the number of people who thought "Learning to use Wordle, Voki or Storybid was easy," tose from $1(16.7 \%)$ for Worle and $0(0 \%)$ for last two to $4(66.7 \%), 4(66.7 \%)$ and $5(83.3 \%)$ respectively.

Participants' attitudes changed positively regarding technology usage to make learning more interesting. In fall 2012, the numer of people who thought, "Wordle or ToonDoo makes learning more interesting," rose from $1(12.5 \%)$ for both to $5(62.5 \%)$ and $6(75 \%)$ respectively. In fall 2013, the number of people who thought, "Voki or Storybird makes learning more interesting " rose from 1 $(16.7 \%)$ and $0(0.0 \%)$ to $5(83.3 \%)$ for boh.

Participants' reported trepidation about technology changed to reflect more confidence. In fall 2012, the number of participants who selected "It is somewhat intimidating to me" decreased from $3(37.5 \%)$ to $1(12.5 \%)$ for Wordle and Toondoo respectively, and from 3 2013 , the number of participants who selected the same statement decreased from $2(32.3 \%)$ to $0(0.0 \%)$ for Wordle; from $4(66.7 \%)$ to $0(0.0 \%)$ for Voki; and from $4(66.7 \%)$ to 1 $(16.7 \%)$ for Storybird.

\section{Findings}

After the training on Web 2.0 technologies, each candidate worked with 1 to 3 struggling readers as a small, guided reading group in the computer lab, with one computer available to each student. The lesson plans each candidate created and their reflection of the lesson along with observatior lesson im qualitative data reflecting the candidates' (1) perception of their experience integrating technology into literacy instruction, and (2) uses of technology in literacy instruction. Additionally, ins candidate reflections were examined for (3) issues and challenges candidates experienced.

Positive perception of experience and acceptance of technology. In both semesters, the majority of participants wrote positively about their experience in reflections, especially on the students' high interest and engagement due to the technology integration. This echoes the positive changes in participants perception that technology makes learning more interesting found in the quantitative questionnaire data. One participant in fal ToonDoo, Toondoo, them freedom to express who they are and what they like as an individual. Students are ready to move on to another skill." Anothe fall 2013 participant wrote about using Voki, "They really enjoyed creating the avatar and recording their voice saying the poem. It was their favorite part of the lesson. The girls were able to hear themselves recite the poem an see if they could do so accurately. It was an assessment tool that also engaged them and seemed like play."

Technology integration to support literacy instruction. The researchers were interested in which of the technologie presented to the candidates would be chosen for inclusion in the lessons and why. In fall 2012 candidates were trained to use Wordle, ToonDoo and Voicethread. Most of the teacher candidates $(\mathrm{n}=7,87.5 \%)$ used Wordle, although one used ToonDoo. No candidate used Voicethread even though it was included in the PD training. In fall 2013 candidates were trained to use Wordle, Voki, and Storybird. Most of the participants $(n=4$ $66.7 \%$ ) used Voki, while two used Storybird.

The technologies were used by the participants to support different purposes and based on the literacy needs of the students in the clinic. Wordle was used for phonics, word study and reading comprehension. Participant integrated Wordle (and all technologies) with print-based books, and other onlin technologies, (e.g., Visual Thesaurus-http:// www.visualthesaurus.com/).For example, in fall 2012, one group read a book titled "Sharks" by Kira Freed (n.d.), and used key words to create a story summary in Wordle a second group read "The Legend of the Bluebonnet" (DePaola, 1996), then create Wordles using descriptor words for the main character; a third group read a story titled "Robot and Mr. Mole" (2004) on http://www. to retell the story (see Figure 1).

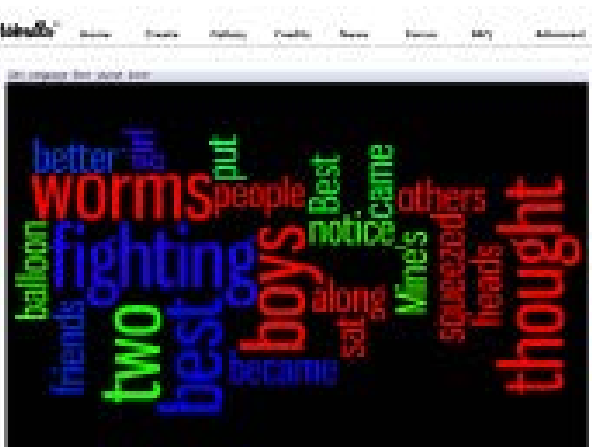

Figure 1. Wordle created in fall 2012 on Robo and Mr. Mole (2004). 
In an extension activity using Wordle, two student teachers designed a word study game for three pairs ( 6 students) to compete with each other. They asked students to spell as many words as they could torhyme with -all, -ight, and -ick, and the group that found the most words won. Students wrote the words with paper and pencil, and then created Wordles using the words that their group found. One participant described this activity with excitement in her reflection, "My four students were all present today. We collaborated with another group of student

The students really enjoyed this activity. They seemed like they understood the concept (about rhyming words) and really enjoyed working on the computer... They impressed me because they were still trying to get more words after the timer went off. They were determined to win and they did. I was proud of my group. They were able to spell all their words correctly in a short amount of time."

While Wordle appeared to be the favored technology in the fall 2012 cohort, one group did use ToonDoo in their work to support student writing in response to reading. The group read "Dragon with a Cold" (Cowley, 1996), and then each student created ToonDoo comic strip to generate a story a person who got sick.

In fall 2013, Voki was the dominant technology chosen by the participants who used it to improve phonological awareness through auditory memory and discriminatio of rhymes, to increase fluency by chora reading, to recall favorite information from nonfiction text, and to enhance comprehension through retelling a story. One participant from the fall 2013 class reflected on her experience of using Voki to increase reading fluency,

" $\mathrm{T}$ and $\mathrm{K}$ really worked hard to create their Voki. Both wanted to repeat the reading several times before recording. Once they did

their final recordings, both showed significant improvement. K showed an improvement of 62 words per minute from her initial reading. $\mathrm{T}$ showed an improvement of 58 words per minute."

Storybird was used in two occasions. In one group, it was used for students to create their own story about sequence. In another account, students used it in a partner (buddy) reading of a leveled non-fiction text first; then theycreated their own original stories using vocabulary words discussed from the nonfiction text using the Storybird website.

In the group that created a story about sequence, students first watched a short video (http://youtu.be/3PtFwlKfvHI) that showed a story with steps in chronological order as a model. Then, they were required to put instructions on how to make a peanut butter and jelly sandwich in the correct sequence using a worksheet. Last, students were asked to use storybird.com to create their own story based on the sequence on their worksheet. The teaser ca teacher candidate evaluated students' learning by checking the order of steps and pictures.

Issues and Challenges. Some issues were observed during the lesson implementation to include: time management, the K-6 students' lack of prerequisite knowledge, behavioral issues caused by the K-6 students' learning differences, and technology proficiency. One participant reflected on a delay during the lesson caused by students' lack of prerequisite knowledge:

"For being in the second and third grade and during election week, I was kind of shocked at how much the students did not know about the vocabulary terms I introduced. Therefore, it took a while for us to go through all of the content vocabulary words so that the students would understand the book. I explained them in terms they understood and they really caught on quickly. We did run out of time doing their Wordles so they did not get to finish..."

Another participant described the difficulty with attention deficit during the Web 2.0 lesson implementation,

Student $O$ and Student A really enjoyed using the computer to show their comprehension of the books that they read. However, both students were only able to retell about $25 \%$ of their stories. Student A has a very difficult time attending, so I brought a hand fidget and that seemed to help a little. During the extensions each student read one page of the story at a time while in a seated position, then when they were finished they stood up and stood behind the chair while the other read their page of the story. We did this to help with Student A's attending issue.

Struggling readers' technology proficiency were also a challenge at times. In some cases, the candidate typed students' retellings into Wordle.net to show students all the importan words from the book because the students could not type independently yet. Readers were also supported by candidates' use of the Wordle Instruction, an instructional document created by the researcher to assist the candidates learn Wordle during the training.

Despite issues and challenges faced during the study, results and findings from the study indicate that the Web 2.0 technology training impacted teacher candidates' acceptance and integration of the Web 2.0 application positively.

\section{Discussion}

\subsection{Serving Best Practices}

Candidates clearly saw that appropriate technology integration to promote interactive learning and student creation of content could lead to increased engagement and increased acquisition of literacy content and skills (Darling-Hammond, et al., 2014)

A case in point is the use of technology observed from one participant working to support learners' overall comprehension and fluency. In this account, the K-6students started the lesson with a partner (buddy) reading of a leveled non-fiction text, Busy Bees by Carol Ghiglieri (2011). The second portion of the lesson consisted of the students creating their own original stories using four of the eight vocabulary words discussed from the non-fiction text using a story book creation website (www storybird.com). This allowed the students to show their knowledge of the words by using them within the correct context in their writing. After their digital books were published on the website, the student shared their finished products and reviewed other young writers' stories published on the Storybird website.

This lesson plan was an excellen representation of reading instruction bes practices (Clark \& Graves, 2005; Iaquinta, 2006 ) in that it expands the basic word study and reading begun in traditional media to a hands-on, real-world performance assessmen supported with technology integration. The learners applied their knowledge of vocabulary and comprehension in appropriate contex by cross-checking their comprehension in collaborative, technology supported reading and writing environment which allowed them

Evidence of participants' acceptance of Web 2.0 technology, pedagogical modeling, and pedagogical application of Web 2.0 technologies, which are considered the three phases in Technological Pedagogical Conten Knowledge (TPACK) development (Koh 
self-reflections. For example, one participant worked in the study to increase her students' fluency by choral reading and to expan their vocabulary through morphology by examining the inflectional ending -ed. Sh adapted the pedagogical model of having student summarize and record reading of story using Voki, which was demonstrated during the training, and designed an activity for struggling readers to record themselves reading the poem, "Foot Repair" by She Silverstein (1998) and to create a Voki using the same text. In response to this experience, she wrote about the students' perceived interest in the lesson content as a result of the lessons' multisensory engagement and thei ease of using Voki.com:

“...They also really loved working on the omputer, creating an avatar, and listening to themselves read the poem. I'm really glad that I learned how to use a technology. It was very easy for my students to use and a wonderful tool for them and myself to hear and monitor their reading. They could even listen to themselves to see if they used appropriate expression and phrasing. Plus, they were actively engaged in the learning process."

In this example, multimodal creation and oral reading by students were used for scaffolding comprehension of word meaning and sentence structure (Clark \& Graves,2005). In this lesson the relationship between ora language and Voki's graphic symbols wer also used to establish the self-monitoring system in Guided Reading (Iaquinta, 2006) which are both considered the best practices for reading instruction.

Technologies included in this study were selected to accommodate the characteristic of the Reading Success Center student in terms of their age, diverse needs, lowe socioeconomic backgrounds, learnin recommendations. These technologies were also selected to help teacher candidates overcome fear of innovation and to prepare them with a solid foundation to start their own exploration or practice using the Web 2.0 technologies for implementation with struggling readers.

Effective reading instruction is characterized by capitalizing on students' interest and experience and providing experiences to engage students (National Council of Teachers of English, 2004). The activities from the lesson plans illustrate that participants were well aware of and appropriately utilizing the multimodal and multimedia functions of the Web 2.0 technologies for stimulating and sustaining learner interest and offering struggling readers opportunities for collaborative interaction and creative meaning making, as the best practices described by An, Aworuwa, Ballard, and Williams(2009).

\subsection{Limitations of the study}

This study's results may not reliably apply to other populations due to the small sample size, the nature of training, and the preliminary stage of Web 2.0 technology empirical research. However, this study provides valuable information to consider in the instructional design of future technology integration and reading pedagogy professional development.

Additional limitations include participants' perceived success in learning the Web 2.0 technologies as specifically tied to the tools presented to them. While the tools for this study were selected with great care and research, other models and other tools may have had more impact than the ones ultimately included in this study.

Finally, findings from this study indicate that teacher candidates might need more training regarding classroom management, specifically in lessons involving technology integration. Based on lesson observations, it may be necessary to include some guidance on time management and controlling disruptive behaviors during future trainings. These issues are also considered barriers to Web 2.0 integration by other researchers(An, Aworuwa, Ballard, \& Williams, 2009) and may to affected the data from this study.

\section{Conclusion/Implications}

Taking into consideration the continuing volution of available technology, it is imperative for teacher education candidates to continue learning and transforming their knowledge and skills around emergin technologies. In this study, participants' perception or attitude changed toward the positive regarding Web 2.0 tools, and the training reduced candidates' fear associated with using the technologies. Hopefully, this experience will encourage these candidates to continue integrating Web 2.0 tools into their instructional practices (Ertmer, OttenbreitLeftwich, Sadic, Sendurur, \& Sendurur, 2012). In addition, participants' lessons and lesson reflections showcase their acceptance of We 2.0 tools, their technology proficiency, their pedagogical modeling, and their pedagogical application of Web 2.0 tools reflect the three phases of Technological Pedagogical Content Knowledge (TPACK) development (Koh \&Divaharan, 2011). This finding might be attributed to the design of the overall PD and study process. The exponential growth of free or inexpensive technologies has made it possible for teachers to employ new strategies for delivering instruction and new techniques for addressing struggling readers' learning. The results from this study may help K-12 teachers in schools and teacher-preparation programs in universities better understand how to include technologies in working with teacher candidates to assist them in designing instructional practices effectively.

\section{Children's Books Cited}

Silverstein, S. (1998). "Foot Repair." In Falling Up: Poems and Drawings. HarperCollins. ISBN:0001857177, 9780001857179

Ghiglieri, C. (2011). Busy Bees. Leveled Nonfiction Passages for Building Comprehension (Readability Levels 2.7 4.2, 5.6) Scholastic, p. 12-17. Retrieved December 16th, 2014 from: http:// www.scholastic.com/content/collateral resources/pdf/73/9780545393973.pdf

Freed, K. (n.d.). Sharks (www.readinga-z. com), Retrieved December 16th, 2014 from:http://www.bisd.net/cms/lib02 TX01001322/Centricity/Domain/1410 Sharks.pdf

DePaola, T. (1996). The legend of the bluebonnet. Puffin; Reissue edition

Cowley, J. (1996). Dragon with a Cold. Wright Group/ McGraw-Hill, 1996. ISBN 0780250583 .

Starfall Learn to Read: Robot and Mr. Mole (2004). Starfall Education, Retrieved December 16th, 2014 from http://www. starfall.com/n/level-a/learn-to-read/load. htm?f.

\section{Technology Applications Used}

Starfall: http://www.starfall.com

Storybird: http://storybird.com

Toondoo: http://www.toondoo.com

Visual Thesaurus: http://www visualthesaurus.com/

Voicethread: http://voicethread.com/ 
Voki:http://voki.com

Wordle: http://www.wordle.net/

\section{References}

An, Y. Aworuwa, B., Ballard, G. \& Williams, K.(2009). Teaching with Web 2.0 Technologies: Benefits, Barriers and Best Practices. Retrieved from: http://www. aect.org/pdf/proceedings09/2009/09_1. pdf

Anderson, P. (2007). What is Web 2.0? Ideas, technologies and implications for education. Technical report, JISC.

Baskerville, D. (2012). Integrating on-line technology into teaching activities to enhance student and teacher learning in a New Zealand primary school, Technology, Pedagogy and Education, 21:1, 119-135, DOI: 10.1080/1475939X.2012.659887. Retrieved December 16th, 2014 from: http://dx doi org/10.1080/147593 9X.2012.659887

Borsheim, C., Merritt, K., \& Reed, D. (2008). Beyond technology for technology's sake: Advancing multiliteracies in the twentyfirst century. A Journal of Educational Strategies, Issues, and Ideas, 82(2), 97-90.

Brunvand, S. \& Byrd, S. (2011). Using VoiceThread to promote learning engagement and success for all students. Teaching Exceptional Children, Vol. 43, No. 4, pp. 28-37Chu, H. C., Hwang, G. J., Tsai, C. C. \& Chen, N. S. (2009). An innovativeapproach for promoting information exchanges and sharing in a web 2.0-basedlearning environment. Interactive Learning Environments, 17(4), 311-323.

Chuang, W. T., Kuo, F. L. Chiang, H. K. , Sud, H. Y. \& Chang, Y. H.(2013). Enhancing Reading Comprehension and Writing Skills among Taiwanese Young EFL Learners Using Digital Storytelling Technique. In L. H. et al. Wong (Eds.). Proceedings of the 21 st International Conference on Computers in Education. Indonesia: Asia-Pacific Society for Computers in Education.
Clark, K. F. \& Graves, M. F. (2005). Scaffolding students' comprehension of text. The Reading Teacher. Volume 58, Issue 6, pages 570-580, March 2005

Cope, B., \& M. Kalantzis. (2000). Multiliteracies: Literacy learning and the design of social futures. London: Routledge.

Darling-Hammond, L., Zielezinski, M. B., \& Goldman, S. (2014). Using Technology to Support At-Risk Students' Learning. Stanford Center for Opportunity Policy in Education (SCOPE) and Alliance for Excellent Education. Retrieved from https://edpolicy.stanford.edu/sites/default/ files/scope-pub-using-technology-report. pdf.

Dewey, J. (1897). My pedagogic creed. School Journal, 54:77-80

Ertmer, P. A., Ottenbreit-Leftwich, A. T., Sadik, O., Sendurur, E., \& Sendurur, P. (2012). Teacher beliefs and technology integration practices: A critical relationship. Computers \& Education, 59(2), 423-435.

Gray, L., Thomas, N., \& Lewis, L. (2010) Teachers use of educational technology in U.S. public schools: 2009 (NCES 2010-040). Retrieved December 16th 2014 from http://nces.ed.gov/pubsearch/ pubsinfo. asp? pubid $=2010040$

Hobgood, B.\& Ormsby, L. (2011), Inclusion in the 21 st-century classroom: Differentiating with technology. Retrieved from: http://www.learnnc.org/lp/editions every-learner/6776

Iaquinta, A. (2006). Guided reading: A research-based response to the challenge of early reading Instruction. Early Childhood Education Journal, Vol. 33, No. 6, June 2006. DOI: 10.1007/s10643-006$0074-2$

International Literacy Association. (2010). International Literacy Association Standards. Retrieved October 17th, 2013.
From http://www.readoregon.org/pdf/ IRAstandards 2010.pdf

International Society for Technology in Education [ISTE]. (2014). National educational technology standards Retrieved December 16th, 2014 from http://www.iste.org/standards

Jewitt, C. (2008). Multimodality and literacy in school classrooms. Review of Research in Education. February 2008 32: 241-267

Koh, J. H., \& Divaharan, H. (2011) Developing pre-service teachers' technology integration expertise through the TPACK-developing instructional model. Journal of Educational Computing Research, 44(1), 35-58.

Larson, L. C., (2008). Electronic reading workshop: Beyond books with new literacies and instructional technologies. Journal of Adolescent and Adult Literacy, 52(2), 121-131.

Madden, M. Chung, P. W. H. \& Dawson, C. W. (2008). The effect of a computer-based cartooning tool on children's cartoons and written stories. Computers \& Education, Volume 51 Issue 2, September, 2008 Pages 900-925.

Malone, T. \& Yoon, J. (2014). Wordle: A case study for learning possibility of vocabulary terms to visual learners. In M. Searson \& M. Ochoa (Eds.), Proceedings of Society for Information Technology \& Teacher Education International Conference 2014 (pp. 2918-2924). Chesapeake, VA: AACE.

McPherson, S., Wang, S. K., Hsu, H. Y. \&Tsuei, M. (2007). New literacies instruction in teacher education. TechTrends: Linking Research and Practice to Improve Learning, 51(5), 2431.

Mills, K. A. (2010) Shrek meets Vygotsky: Rethinking adolescents' multimodal literacy practices in schools. Journal of Adolescent and Adult Literacy, 54(1). pp. 
$35-41$

Molnar, M. (2014). Richard Culatta: Five Ways Technology Can Close Equity Gaps. Education Week. Retrieved July 5, 2017 from: https://marketbrief.edweek.org/ marketplace-k-12/richard_culatta_five ways_technology_can_close_equity gaps/

National Council of Teachers of English (NCTE) (2002). Annual Report. Urbana, IL: Author.

National Council of Teachers of English. (May $1,2004)$. On reading, learning to read, and effective reading instruction: An overview of what we know and how we know It. Retrieved December 16,2014 from: http://www.ncte.org/positions/statements/ onreading

O’Byrne, B., Bailey, D. \& Murrell, S. (2011) Literacy in multimedia environments: Preliminary findings. In M. Koehler \& P. Mishra (Eds.), Proceedings of Society for Information Technology \& Teacher Education International Conference 2011 (pp. 1600-1606). Chesapeake, VA: AACE Retrieved October 17, 2013 from http:// www.editlib.org/p/36526.

Oliver, K., Pritchard, R. \& Watson, T. (2013) Teachers abroad: Integrating writing and technology. In R. McBride \& M. Searson (Eds.), Proceedings of Society for Information Technology \& Teacher Education International Conference 2013 (pp. 3532-3539). Chesapeake, VA: AACE Retrieved October 17, 2013 from http:// www.editlib.org/p/48646.

O'Reilly, T. (2005). What is Web 2.0: design patterns and business models for the nex generation of software. Retrieved Octobe 17th, 2013 from http://www.oreilly.com/ pub/a/oreilly/tim/news/2005/09/30/whatis-web-20.html.

Smaldino, S. E. Lowther, D. L., \& Russell, J. W. (2012).Instructional Technology and Media for Learning. (10th Edition).
Pearson Education, Inc., Boston, Ma.

Strauss, A. \& Corbin, J. (1998). Basics of Qualitative Research: Techniques and Procedures for Developing Grounded Theory. SAGE Publications.

Taylor, M. (2012). Using technology to motivate reluctant writers in a third grade classroom. Journal of School Connections. Fall 2012, Vol. 4, No. 1, pp. 81-95

The Annie E. Casey Foundation. (2014). Race for results: Building a path to opportunity for all children. Retrieved December 16th, 2014 from: http://www.aradvocates. org/assets/PDFs/Kids-Count/Race-forResults-Report-2014.pdf

U.S. Department of Education (2017), Office of Educational Technology, Reimagining the Role of Technology in Education: 2017 National Education Technology Plan Update, Washington, D.C., 2017. Retrieved from:https://tech.ed.gov/ files/2017/01/NETP17.pdf

Wake, D. (2013). Teacher candidates' perceptions of technology used to support literacy practices. In J. Whittingham, S. Huffman, W. Rickman, \& C. Wiedmaier (Eds.), Technological tools for the literacy classroom (pp. 220-242). Hershey, PA: IGI Global.

Wake, D. \& Whittingham, J. (2013). Teacher candidates' perceptions of technology supported literacy practices. Contemporary Issues in Technology and Teacher Education, 13(3). Retrieved from http://www.citejournal.org/vol13/iss3/ languagearts/article1.cfm.

\section{Contact the Author}

Dr. Haihong (Helen) Hu

Associate Professor, Instructional Technology Program, Department of Leadership Studies, College of Education,

University of Central Arkansas

Email: hhu@uca.edu

\section{Dr. Mary Ellen Oslic}

Assistant Professor of Literacy Education at Stetson University in DeLand, Florida

\section{Dr. Donna Wake}

Associate Dean in the University of Central Arkansas College of Education and an Associate Professor in the Department of Teaching and Learning. 